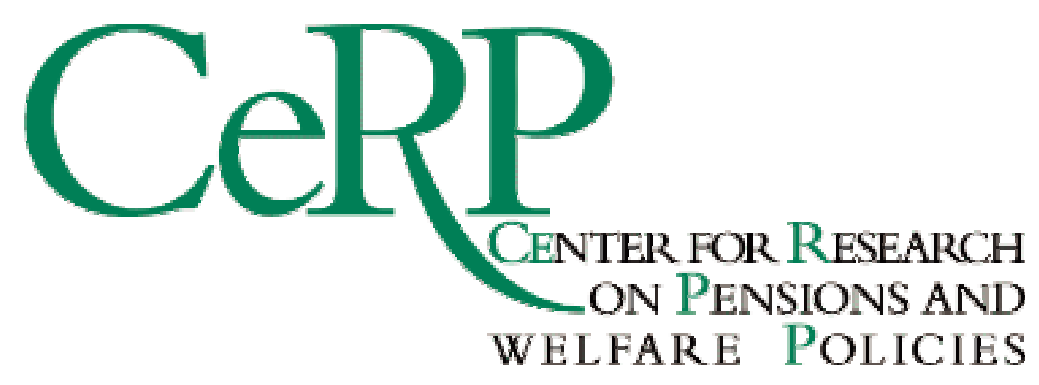

Working Paper 48/06

PUBLIC POLICY AND THE TRANSITION TO PRIVATE PENSION PROVISION IN THE UNITED STATES AND EUROPE

Onorato Castellino

Elsa Fornero 
Onorato Castellino - Elsa Fornero

(Università di Torino and CeRP)

Version March $13^{\text {th, }} 2006$

\title{
PUBLIC POLICY AND THE TRANSITION TO PRIVATE PENSION PROVISION IN THE UNITED STATES AND EUROPE
}

\begin{abstract}
PAYG and funding may and do coexist in social security systems. The proportions of this coexistence, however, are quite variable from country to country. The paper examines the US and a number of European countries, looking at both the present state and the foreseeable trends in future decades. The impact of a mixed system is analysed under the relevant viewpoints, with special reference to the adequacy and sustainability of the overall structure and to the distribution of risk.
\end{abstract}

Index

1. Introduction

2. Private vs. public pensions: a blurred distinction?

3. Reasons behind the development of private, funded pensions

4. Private pensions in the US: main features and recent trends

5. Private pensions in Europe: main features and recent trends

6. An overall assessment

7. The shift in the distribution of risk

8. The role of regulation in the mitigation of risk

9. Conclusions

\footnotetext{
- We thank Alessandro Dovis and Filippo Maggi, graduate students at the University of Turin, for their helpful research assistantship. Financial support by MIUR (Italian Ministry of Education, University and Research) is gratefully acknowledged.
} 


\section{Introduction}

The demographic transition has brought pensions reform to the forefront of the policy agenda both in Europe and in the US. Confronted with swift population ageing, practically all European Countries and the US as well have implemented, or planned, or at least discussed, pension reforms, often entailing rather radical changes.

In many European countries - such as France, Germany or Italy - the financial sustainability of the systems has been the main goal. Retirement ages have been raised; replacement rates of public PAYGO systems have been reduced; benefits have been indexed to wages rather than to prices; the correlation of benefits to contributions has been strengthened, in some cases to the point of changing the pension formula from a defined benefits to a defined contributions type. In order to restore the (future) adequacy of benefits levels, curtailed by the restructuring of systems, efforts have been undertaken to encourage the private provision of retirement income and the building (or strengthening) of funded pension components, in the form of both occupational and personal pensions. There is, however, a broad consensus that more needs to be achieved, particularly in the fields of retirement age increase and of private pension provision.

In oher European countries (such as the UK and the Netherlands), the private pillar is already an established feature, and its contribution to pensioners' welfare a major one. This by no means implies that the overall provision of income for old age is deemed a satisfactory one: in the U. K., for instance, the "Turner report" has recently suggested major interventions.

The US have smaller problems in social security and are similar to the UK and the Netherlands as they rely heavily on private pensions. So far, the reforms enacted in the US are to be seen more as discretionary "adjustments" to the system (which already has automatic stabilizers) than a fundamental change in the design. Also in the US, however, a proposal is pending for a radical switch of Social Security from PAYG to funding.

The content of the chapter is the following. After defining our field (sec. 2), we turn to the logic of a mixed PAYG-funded system (sec. 3). The main features of the US and the European systems and their directions of reform are dealt with in sections 4 and 5. A number of comments is offered in sec. 6, including the general phylosophy of national systems, the interaction between public and private pensions, the trend away of defined benefits and towards defined contributions schemes. Various aspects of risk are more specifically handled in sec. 7 and the role of regulation in sec. 8. Section 9 concludes.

\section{Private vs. public pensions: a blurred distinction?}

In principle, the realm of private pensions should be that of fully funded, actuarially based voluntary pensions, either employment-related and collective (sectorwide or company based; closed or open), or bought individually in insurance markets. Conversely, the public system (social security) is normally conceived as a mandatory and redistributive PAYG mechanism, run by the state and financed out of payroll and/or general taxes. 
The real world is much less clear-cut, as features of the public system are also present in the private one, and vice versa. It sometimes happens that private schemes are run on a PAYG basis (quite a common arrangement for occupational pension funds in France, but also in Italy, where schemes for some professional categories are unfunded and thus, necessarily, compulsory); that public PAYG systems accumulate reserves on a prudential basis or that they mimic private insurance contracts, without resorting to funding, as in the so-called Notional Defined Contribution (NDC) system; that participation in pension funds, which typically should be left to individual choice, is instead mandatory, as it often happens in agreements between employers and unions; that private pensions are backed not only by an effective regulation and supervision of financial and insurance markets, but also by a public guarantee (which is equivalent to reintroducing elements of PAYG financing).

This grey area can be traced back to the large variety of today's pension systems, which of course are not the deliberate outcome of some rational choice, taken in a framework of complete information and perfect foresight, but instead the stratification of successive law-making, reflecting quite different national histories and social values. Even when one limits the perspective to European countries, heterogeneity of situations and rules still prevails, irrespective of more uniform trends induced by the reform process.

The vocabulary itself differs so that a neat classification, as a first step to international comparisons, evaluation and monitoring, is difficult to obtain. Recently, efforts have been devoted to clarify the terminology and provide an accepted classification, both in order to promote harmonisation in pension statistics for policy use and to avoid misinterpretation of public finances in view of compliance with the European stability pact (Eurostat, 2004). This process concerns both public and private pensions and is still ongoing. For the present study, we conform to the OECD classification (2005a, p.12), which considers as private those pension schemes administered by an institution other than general government. As a consequence, a whole variety of pension plans can be recorded as private pensions; indeed any form of savings for retirement not managed by the state ${ }^{1}$. Within this rather general class of savings instruments, however, due to space and data constraints, we will greatly privilege occupational pension plans, irrespective of whether they are voluntary or mandatory, of their primary or supplementary role as a source of retirement income, of their DB vs. DC characterisation.

\section{Reasons behind the development of private, funded pensions}

The future outlook of private pensions - in terms of both quantitative developments of participants and accumulated funds, and of qualitative modifications of past arrangements - can be traced back to three main factors:

- a retrenchment of public systems, which creates scope and room for a private component;

- a reshaping of labour market relationships in the direction of an increased flexibility, as well as of greater portability of pension rights;

\footnotetext{
${ }^{1}$ A different taxonomy, which looks at the functions and target groups of the different pension schemes, has been suggested by Holzmann and Hinz (2005, p. 10).
} 
- a deliberate policy-move in the direction of a mixed system, combining PAYG/funding and public/private features as a better insurance design.

The first factor (for an analysis of which we refer to the chapter by Francese, Franco and Tommasino in this volume) seems prominent in determining the future evolution of private pensions in Western Europe, in response to both population ageing and the myopia of past policy. Cutting back public pension expenditure is a "natural" response to the financial unsustainability of the systems created by demographic pressures and badly designed pension formulae. In presence of stringent constraints to increase the payroll tax rates, workers (in particular, the younger cohorts) thus continue to pay the previous contribution rate, but will get back less than was awarded to older generations. This is why, along with the restrictions in the public provision, the state encourages the accumulation of private pension wealth ${ }^{2}$.

The reshaping of labour market relationships - the second factor - is important in those countries where occupational plans of the traditional DB type have a long tradition: typically the US and, in Europe, the UK, but also Switzerland and the Netherlands (see box 1). It is a process which implies a reallocation of risks away from firms and towards workers and which is dictated, from the standpoint of firms, by their increasing difficulties in keeping past promises and commitments, and in renewing them to the new cohorts of workers; and from the point of view of employees, by their greater mobility between firms. Indeed, many of the deficiencies undermining the stability of the public PAYG systems also characterize the traditional occupational pension plans: too generous pension formulae of the DB type, unsustainable long run obligations and unfunded liabilities; idiosyncratic disparities of treatment; encouragement to early leave and other distortions to the labour supply. These shortcomings demand changes, many of which are already in progress, that will profoundly modify the landscape of occupational pensions both in the US and in the EU in the near future.

$\begin{aligned} & \text { Box 1. Employer-sponsored schemes: from an instrument of personnel } \\ & \text { management to a company burden? } \\ & \text { Employer-sponsored schemes grew substantially in the past century as an } \\ & \text { important part of the industrial-labour relationships. This occurred particularly in } \\ & \text { countries where the public schemes provided but a very limited coverage, } \\ & \text { suggesting a supplementary role of occupational, company-based pensions with } \\ & \text { respect to the "safety net" guaranteed by the state. } \\ & \text { Company pension plans were also an important element of the so called } \\ & \text { "internal" labour market, providing a long term bond between employer and } \\ & \text { employee, functional to a labour market in which stability was more important, to } \\ & \text { the employer, then flexibility. Pension formulae of these plans were therefore } \\ & \text { designed "to lock in" the workers to the firm for a long horizon, by means of } \\ & \text { various kind of incentives to stay (such as a "back loading" factor in the pension } \\ & \text { formula and other forms of "wage tilt", compensating lengthy careers), but also to } \\ & \text { encourage and enable retirement at some point. }\end{aligned}$

\footnotetext{
${ }^{2}$ From a macroeconomic perspective, it is not clear whether this will result in new savings rather than in just a reallocation of already formed savings: a question that has stimulated an endless controversy among economists, as yet unsettled by empirical analysis. See for instance Feldstein 1996, secs. III and VI; Diamond and Horszag 2004, pp. 47-54; Holzmann and Hinz 2005, pp. 45-47.
} 


Usually of the defined benefit type, with a guarantee provided by the
employer, this kind of pension schemes constituted a very flexible instrument,
allowing for wide discretion for firms in determining the level of benefits, the
degree of funding, the age of retirement. Firms preferred long-staying workers
because of economies in the cost of personnel management (such as recruitment
and training expenses), and because of likely positive effects on productivity.
These could depend on the capability of the pension provision to act as a selection
mechanism, i.e. to attract the best workers, endowed with desirable characteristics
from the employer's point of view: more far-sighted, trustworthy, less prone to the
shirking type of behaviour; in a word, more productive. Trade unions, and
employees, were also favourable to company-based pension plans because they
considered the old age "insurance" they provided an addition to the overall
compensation package. In general, both parties were encouraged towards this
arrangement by favourable tax treatments.
Over time, traditional company pensions have experienced many changes,
and are now living through difficult times. First, in order to enhance the protection
of members, the past discretion has been reduced and replaced by a tighter public
regulation. Second, labour markets have shifted towards a greater flexibility;
instead of rewarding long term tenures and job stability, the issue is now the
"portability" of pension rights, a feature which seems more responsive to a mobile
workforce and more apt to meet the requirements of firms. Third, because of
(sometimes huge) funding shortfalls, DB pension plans are now often considered
more a burden than a valuable instrument of personnel management; very likely,
the switch from DB to DC will thus continue, both through the re-engineering of
existing schemes and the establishment of new plans entirely DC.
• A recent, conspicuous example is IBM, which announced, as of January 2006 , it would
freeze its DB pension scheme, and force its 125.000 US employees to participate into a DC scheme.

The third factor, the construction of a mixed system as an instrument for the diversification of pension risk, was taken up as the guiding principle for pension reform by international institutions like the World Bank, and used as a sort of "recommendation" for countries in need of support to sustain the reform process. For this reason, it played an important role in some Latin American and Eastern European Countries, where, often after a political shock and the collapse of the previous political regime, the social protection system had to be reorganised almost from scratch. In the rest of Europe, as will be seen in sec. 5, a mixed system already exists in some countries (e. g. the UK and the Netherlands), while others are more or less successfully trying to foster it.

The "mixed system" can be interpreted as the solution, both at the empirical and the theoretical level, to the long standing funding/PAYG controversy. The standard argument in favour of the former lies in the comparison between the rate of return of assets invested in capital markets and the implicit rate of return of PAYG, the former being taken (again on the basis of both theoretical arguments and empirical observations) to be considerably higher than the latter. Scholars who advocate funding usually suggest that the long run real return of equities is of the order of 6-7 per cent, so that also a mixed equities-bond portfolio could afford a return of about 5 percent (see Feldstein 1996; Siegel 1998, passim; Modigliani et al., 2001; Dimson et al., 2002, particularly ch. 4); while the rate of growth of earnings (proxied by the GDP growth rate) is forecast, for advanced countries and over the long run, at about 1.5-2 per cent. Whatever the validity of this view in general terms, a number of caveats are in order. 
First, past experience is not necessarily a strong basis for forecasting the future. Diamond (1999a) lists a number of convincing reasons (such as recent developments in the capital market and the expectation of slower economic growth in the future) why the future equity premium could be declining, as compared with the past.

Second, higher returns from equities are a compensation for their higher degree of risk. A pronounced volatility could impair the attitude of funding to satisfy old-age needs, as has been stressed, for instance, by Modigliani et al. (2001) and Diamond and Orszag (2004, pp. 40, 134, 147-151). Some suggest that this risk could be covered by resorting to the derivatives market, or simply by setting aside a small percentage of the return; but Modigliani et al. (2001, pp. 8-9 and 34) and Modigliani and Muralidhar (2004, pp. 35, 75-84, 120-121) strongly advocate a return guarantee by the State.

Third, for most countries (and certainly for those we are dealing with in the present paper) the current problem is not to decide whether to create ex nihilo a funded or a PAYG scheme, but whether to favour the birth, or the growth, of a funded scheme side by side with an already existing, and developed, PAYG one in need of reform in itself. While the former situation basically implies comparing two steady states, in the latter a transition problem is superimposed on the rates of return comparison, as the growth of funding is seen as a countermeasure for the reduction of the PAYG coverage. To put it bluntly: if young workers are told that they will receive lower pensions for the same payroll tax rate, and invited to contribute to a funded pillar as an offsetting measure, they are asked to save more for the same replacement ratio. If, instead, contributions to the funded pillar are compensated by a reduction of the payroll tax rate, obligations to present and prospective retirees must be partly covered by other means (i.e. from general taxation). An even partial transition from PAYG to funding, therefore, can only be a very gradual one, and an awkward political decision has to be taken as to how to share the implied cost between present and prospective pensioners, present workers and taxpayers.

What all these caveats boil down to is that, where a significant PAYG system already exists, the realistic choice is not to overhaul the status quo by a 100 per cent switch to funding, but to have a private funded provision complementing the public PAYG system.

At the theoretical level, the mixed system represents more than a necessary second best solution. Given two assets with different expected returns and different risks, a mixed portfolio combining them offers an expected return equal to the weighted average of their returns, while its risk depends not only on the individual risks but also on their correlation. Mixed portfolios - if their returns are not (or at least not higly) correlated - may therefore enrich the set of available opportunities in the risk-return space $^{3}$. This principle may be directly applied to a mixed PAYG-funded portfolio. The internal rate of the PAYG component is linked to the rate of growth of GDP (or to the rate of increase of the wage bill), which prima facie can be taken as stochastically independent from, or at least not highly correlated with, financial markets returns ${ }^{4}$.

This point will be taken again in section 7; be it sufficient here to emphasize that a "privatisation fever" aiming at a conversion to full funding never spread through

\footnotetext{
${ }^{3}$ Risk is defined here, according to the standard Markowitz-Tobin model, as the standard deviation of possible outcomes around their mean. The advantages of a low (and a fortiori a null or a negative) risk correlation are rigorously presented in Tobin (1965), pp. 22-30.

${ }^{4}$ On these points see Lindbeck and Persson (2003), pp. 98-101.
} 
Europe, a position strengthened, on an empirical basis, by the rather uncertain support offered by the long run performance of European financial markets.

\section{Private Pensions in the US: main features and recent trends}

American public pensions are based on the Social Security System, covering all workers (employees and self-employed). Contributions are paid at the rate of 12.4 per cent on all labor incomes up to the maximum taxable earnings base (now set at 90,000 dollars a year or about 2.5 times the average wage). If a worker retires at the standard age (65 in 1999, gradually rising to 67), the pension formula is based on the average (indexed to average wages) monthly wage of his best 35 years, and is highly progressive: $90 \%$ on the first bracket (about 8 per cent of the ceiling), $32 \%$ on the second (about 42 per cent of the ceiling), and $15 \%$ on the remaining amount up to the ceiling (adjusted every year in line with the growth of average wages) ${ }^{5}$. Calculations by the Social Security Administration (Board of Trustees 2005, pp. 186-7) show that the replacement rate in 2005 for the standard age is 58.3, 43.2, 36.1 and 30.1 per cent according to whether the worker's earnings amount to $45,100,160$ per cent of the average wage index or to the ceiling ${ }^{6}$. following ${ }^{7}$ :

Private pensions may take a number of different forms, the main ones being the

- occupational plans, of the DB or DC type ${ }^{8}$, sponsored by one or more employer(s), voluntarily or after bargaining with the unions;

- 401(k) plans, created from 1978 onwards; they may be incorporated into occupational plans of the defined contribution type;

- Individual Retirement Accounts (IRAs), of which there are several types; two (SIMPLE and SEP) are employer sponsored.

Occupational pension plans expanded rapidly in the first decades after the second World War, when the proportion of private sector workers covered by them increased rapidly; since the Seventies it is fairly stable at about 50 per cent. In the last two decades of the last century, the share of defined contributions plans, and between them of $401(\mathrm{k})$ plans in particular, grew steadily and changed the landscape radically".

Given the progressive formula of Social Security, it is clear that its benefits are an important source of income for low earners. They account for more than half of total income for almost two-thirds of beneficiaries above age 65 , for more than 90 per cent for almost one third, and for the whole income for one fifth (Social Security Administration 2005). On the other side, high and medium income level households usually rely on private pension provision (but also on asset income and earnings) in

\footnotetext{
${ }^{5}$ Early (but not before age 62) or late leavers receive a lower or a higher amount, depending on the distance from the standard age.

${ }^{6}$ The definition of average earnings is similar to the one used for table 2, but the denominator is average real lifetime (and not last year) earnings.

${ }^{7}$ For further details, see Diamond and Orszag (2004), Appendix D.

${ }^{8}$ An intermediate solution between DB and DC is offered by the so-called hybrid plans: see Munnell and Sundén 2004, pp. 17-18; Clark and Schieber 2004.

${ }^{9}$ See Munnell and Sundén 2001, passim, but especially figs. 1 and 9.
} 
order to obtain an adequate income in old age ${ }^{10}$. According to a survey (Federal Interagency Forum 2000, tables 8A and 8B), in 1998 income from Social Security amounted to 38 per cent of all income for the 65 -year-and-more old, but the percentage declined from 82.1 in the lowest quintile to 18.3 in the highest ${ }^{11}$.

It is interesting to look (table 1) at the amount of the pension benefits coming from the different sources in 1980 and 2000 (the last year for which data is available); all figures are rounded ${ }^{12}$.

Table 1

Pension benefits from different sources

\begin{tabular}{lcccc} 
& & 1980 & \multicolumn{2}{c}{2000} \\
& \$ billion & $\%$ & \$ billion & $\%$ \\
Social Security & 105 & 75 & 353 & 51 \\
Occupational Funds & 35 & 25 & 341 & 49
\end{tabular}

The combination of a public/PAYG and a private/funded pillar seems a rather balanced one. Yet the US pension system has lately been the subject of a lively debate, given that the cost of benefits is forecast to exceed payroll tax revenues starting in 2017, and the Trust Fund to be exhausted in 2041 (Board of Trustees 2005). A number of proposals have been made to tackle this problem in advance and, as already mentioned in sec. 3, many scholars have emphasized the possibility and the advisability of a switch of Social Security from PAYG to funding. In December 2001, the President's Commission to Strengthen Social Security issued a report suggesting three alternative models, all of them including an improvement of the fiscal sustainability of the present system, a voluntary personal retirement account and (given reasonable rates of return) an increase in total benefits as compared with current retirees. Although the proposal to strengthen funding has been endorsed by President Bush in his re-election campaign, no substantial innovation has been legislated so far.

\section{Private pensions in Europe: main features and recent trends}

The fifteen older EU countries (and even more so the enlarged twenty-five ones) build up a very complex and differentiated group. History, tradition and political choice have left their ineffaceable mark, so that each country offers its own pattern of pension institutions (Castellino and Fornero 2003). To consider each country separately would be an overly complicated task, and too many trees would prevent us from seeing the forest $^{13}$. We therefore concentrate our attention on seven countries altogether: the five

\footnotetext{
${ }^{10}$ On the correlation between earnings and pension fund participation, see for instance Munnell and Sundén 2004, ch. 3.

${ }^{11}$ For the top quintile, asset income accounted for 27.9 per cent and earnings for a surprising (given the age bracket) 31.1 per cent.

12 Source: Board of Trustees 2005, table VI.A2; US Department of Labor 2005, table A4. Social Security benefits relate to old-age and survivors; including disability they add up to 121 billion in 1980 and 408 in 2000 .

${ }^{13}$ Furthermore, this very heterogeneity prevents us from following, while dealing with the European countries, the same format as for the US.
} 
biggest ones (France, Germany, Italy, Spain and the UK), plus the Netherlands and Sweden, which are representative of various "social models", in accordance to the taxonomy introduced by Esping Andersen (1990). Even so, many individual features will be overlooked, and only the general trends (if any) identified.

Francese, Franco and Tommasino, in their contribution to this volume, review the public pension reform process which has taken place in Europe during the last 10-15 years. Be it sufficient here to recall that public pension schemes are normally of the PAYG type; and that these reforms have mainly been spurred by the need to tackle the (present and/or prospective) financial imbalances caused by both too lavish and shortsighted systems and by trends constantly reducing the ratio between workers and pensioners. Demography is not the only factor impacting on this ratio: activity rates and the length of working life also exert their influence. Another reason for reform has been the growing awareness of the perverse incentives that existing schemes offered to earlier retirement, so that pension age stagnated and often decreased at the same time when life expectancy steadily increased.

Most of the above mentioned countries have therefore recently adopted measures aimed at curbing the dynamics of public pension expenditure by increasing pension age, by reducing replacement rates, by drastically modifying (as did Italy in 1995 and Sweden in 1998) the pension formula from a defined benefits to a (notional) defined contributions (NDC) type, and, last but not least, by cooling indexation mechanisms.

One may now turn to a recent report by the European Commission (2004, passim) showing the replacement rates from the first and the second pillar, both for the year 2002 or 2003 (actual) and the year 2050 (projected). The results (table 2) refer to a career length of 40 years and a retirement age of $65^{14}$.

Table 2

Actual and prospective replacement rates (percentage values)

\begin{tabular}{lcccc} 
Country & \multicolumn{2}{c}{ First pillar } & \multicolumn{2}{c}{ Second pillar } \\
& 2003 & 2050 & 2003 & 2050 \\
France & 65 & 57 & N.A. & N.A. \\
Germany & 45 & 38 & 6 & 13 \\
Italy & 80 & 65 & 0 & 20 \\
Netherlands & 33 & 33 & 37 & 37 \\
Spain & 89 & 83 & N.A. & N.A. \\
Sweden & 57 & 40 & 14 & 14 \\
UK & 17 & 11 & 50 & 50
\end{tabular}

\footnotetext{
${ }^{14}$ Earnings are supposed to correspond to the average over the whole working life (figures are given also for other profiles, but are not reported here). Replacement rates are calculated by dividing the pension income during the first year of retirement by the income during the year preceding retirement. The table shows gross replacement rates (net replacement rates, also calculated and not reported here, are higher because subtracting social insurance contributions and taxes reduces the denominator proportionally more than the numerator). For countries with several schemes, the most prevalent one is taken into account.

The European Commission (2004, pp. 9-10) recommends that the above results, although based on an attempt to collect figures from the Member States under a common definition, be taken only as a first approximation.
} 
The first pillar figures are comparatively high for Spain, Italy and France; intermediate for Sweden and Germany; low for the Netherlands and the UK. But in all cases, except the Netherlands, these figures are expected to go down in the first half of the century, as a consequence of the measures adopted as above ${ }^{15}$.

Before commenting on the second pillar, it is useful to look also at table 3, taken from another recent report (European Commission 2005, pp. 11-12) and offering some data on the coverage (workers covered over the workforce) and on the contribution to pensioners' income by the second pillar. Although not expressly stated in the report, the data refer to the present situation (around the year 2005).

Table 3

Some data on the second pillar (percentage values)

$\begin{array}{lcc}\text { Country } & \text { Coverage rates } & \text { Contribution to pensioners' income } \\ \text { France } & 10 & 3 \\ \text { Germany } & 57 & 6 \\ \text { Italy } & 15^{16} & \text { Negligible } \\ \text { Netherlands } & 90 & 34 \\ \text { Spain } & 10 & \text { (not available) } \\ \text { Sweden } & 90 & 18 \\ \text { United Kingdom } & 43 & 30\end{array}$

The same pattern emerges from a different viewpoint (pension funds assets as a percentage of GNP): the figure is very high for the Netherlands and the UK, considerably lower for Sweden and even lower for the other countries ${ }^{17}$.

The picture of the second pillar within the European Union is therefore, as expected, a mixed one. Although the figures on replacement rates, coverage, contribution to pensioners' income and assets over GDP are not perfectly correlated, it is clear that the seven countries considered may be divided into three classes. The UK and the Netherlands stand out for a much stronger role of the second pillar, as compared both with the first pillar in the same two countries and the second pillar in the other five. At the opposite end, three countries (France, Italy and Spain) are still in the initial

15 The reduction is particularly striking for the UK, but a different source (National Strategy Report 2005, p. 51) suggests a higher figure (19 per cent).

${ }^{16}$ The figure refers only to employees occupational schemes and is taken from COVIP (2005), p. 127. The coverage for the self-employed is much lower.

${ }^{17}$ To some surprise, data from different sources are often erratic, probably due to differences in definitions, which are however difficult to ascertain (the reference years may also be different, but close to each other). Two striking examples: for the UK, the assets/GDP percentage ratio is 65 according to OECD 2005b, p. 4, and 102 according to European Commission 2005, p. 13. For Sweden, according to the same sources, this rate is 13 and 34 . Other relevant discrepancies emerge when comparing these two sources with European Commission 2003, p. 79. 
phase. Germany and Sweden are somewhat in-between, but closer to the lower than to the higher end.

As an obvious countermeasure to the trimming of the first pillar, and in order to avoid a future decrease in the income of the elderly, efforts have been made to increase the contribution of second pillar pensions (see box 2).

\section{Box 2. Policies fostering the second pillar}

First, the institutional framework for pension funds (and private insurance for old age) has been reinforced as follows:

France has introduced in 2003 the second pillar Plan d'épargne pour la retraite collectif (PERCO) and the third pillar Plan d'épargne retraite populaire (PERP);

in Germany, the "Riester Reform" (2001) has entitled workers, if they so wish, to convert part of their salary into pension contributions and has favoured agreements between employers and employees on occupational retirement provisions through the introduction of a new legal entity (Pensionsfonds);

Italy has laboriously tried not only to regulate pension funds (1992 and 1995), but also to favour their growth by diverting to them the annual flow of Trattamento di Fine Rapporto (TFR), now a book reserve in the firms' balance sheet paid to workers on termination of their labour relationship;

in Spain, a decree of 2004 systematizes and completes the regulations relating to pension plans and pension funds, and the Government is committed to promote the development of complementary provisions so as to reach, within a decade, the majority of workers;

in Sweden (in addition to occupational pensions collectively agreed upon) 2.5 per cent of the payroll tax has been shifted (1999) from PAYG to a funded scheme, managed by a private fund chosen by the employee;

in the UK, as is well known, individuals can choose to contract out of part of the first pillar (the "State second pension") in favour of an occupational or a personal pension scheme. In 2001 a new form of private pension ("Stakeholder pension scheme") has been introduced, mainly in order to extend the coverage, at low cost, to small firms' workers with moderate incomes.

In many countries, the institutional framework has also been strengthened by improving regulation and prudential requirements, or by tilting the final choice between an annuity and a lump sum in favour of the former. Not less important is the information effort aimed at inducing workers to consider the effects of the first pillar reforms and to increase their participation to other forms of providing for their old age.

A second channel, mandatory or quasi-mandatory rules, may also be resorted to. In the Netherlands, compulsory participation to a pension fund applies to the self-employed, and has been discussed also for employees in order to reduce the "white spot" of insufficient coverage. Since 1999, as already mentioned, the Swedish public system entails a funded component. For the UK, the Turner Report has suggested the creation of a low cost, national funded pension saving scheme into which individuals would be automatically enrolled, but with the right to opt out. In Italy - where participation in pension funds is voluntary and, after 10 years from their introduction, the number of workers enrolled is not encouraging - the government enacted in December 2005 a new bill, which changes the default option from "non participation" into "participation" in case the worker does not explicitly manifest his/her will. The same bill, however, postponed until 2008 the application of the new rules. 
In most countries, a third channel for encouraging the growth of pension funds has been identified in tax exemptions, both in terms of tax free contributions (usually up to a ceiling) and of lighter taxation of the funds' capital income. Even if taxation is eventually applied "downstream", when benefits are paid out, the EET method (exemption/exemption/taxation) is beneficial to workers both because of its financial effect (taxes are paid later) and because, under progressive taxation, the marginal rate is lower (aggregate income being also lower) at the time of retirement as compared with the working years. France in 2003, Germany in 2004, Italy in 2000 and the UK in 2004 have also rationalized their system of privileged taxation of pension savings (in Italy, benefits were previously accorded to all insurance contracts but are now limited to saving arrangements leading to an annuity; in the UK, starting from 2006 , there will be a single regime instead of the eight previously existing!).

A fourth channel may be represented by subsidies. The German reform of 2001 has introduced for workers the possibility of choosing between a subsidy and a tax allowance, whatever the more convenient. The subsidy is made up of a basic subsidy and a child subsidy for each child and is conditional on a given percentage of income being saved. Since the subsidy is determined as an absolute amount, and moreover it concurs to the requested percentage saving, it is very generous with low incomes ${ }^{18}$.

All these measures are supposed to impact on the number of workers covered by the second pillar and to increase their average contribution period and therefore their replacement rate. Any forecast of these consequences over the next decades cannot however be more than a rough guess.

As far as coverage is concerned (an already high figure in the Netherlands and Sweden and somewhat lower in the UK), it is likely to increase in Germany, thanks to the satisfactory response to the Riester incentives, and in Italy, owing to the new nature of the default option. For France, even after the measures adopted in 2003, the official estimate (National Strategy Report 2005, p. 7 and Annex 5) is that occupational pensions will continue to play a minor role. In Spain, the effect of the incentives adopted is apparently concentrated on the third pillar (National Strategy Report 2005, p. 17).

As to the replacement rates in the year 2050 for a full career, table 2 imagines a significant increase for Germany and a jump from 0 to 20 per cent for Italy, based on the assumption that some $10 \%$ of the employees' income (the flow of TFR plus an additional contribution by employer and worker) will be paid into a pension fund. No change is expected between 2003 and 2050 for the Netherlands, Sweden and the UK ${ }^{19}$.

${ }^{18}$ Both the subsidy and the required percentage saving increase over time in two-years steps between 2002 and 2008. From 2008 onwards the percentage will be 4 per cent, the basic subsidy 154 euros a year and the child subsidy 185 euros a year. Also non earning parents caring for children are entitled to the basic subsidy. As an example, let us consider a one-earner couple with two children and an income of 20.000 euros. The requested saving is 800 euros. The subsidy adds up to $2 \times 154+2 \times 185=$ 678 euros. The saving effort actually requested by the family is then only $(800-678=) 122$ euros. (A lower income or a higher number of children would lead to a negative result, but a minimum saving effort is required).

${ }^{19}$ In another report by the European Commission (2005, pp. 26-27), framed in terms not of replacement rates but of contribution to retired people income, second pillar figures for the Netherlands and the UK are increasing between 2003 and 2050. 
The general conclusion may tentatively be expressed as follows. Reforms in the PAYG pillar, increasing awareness of its reduced contribution to pensioners' income and policy measures in favour of funded schemes have opened new perspectives to the second pillar in those countries where it was not relevant. This does not seem, however, to lead to important results in France nor in Spain (but in the latter case insurance policies could be more effective). Germany and Italy appear to be the most sensitive to the new wind.

\section{An overall assessment}

a) The philosophy of national systems. In order to discuss the common traits and the differences between the national systems we have been considering, let us take the US as our reference point.

The stylized philosophy of the US system may be expressed as follows. The public, compulsory, Social Security scheme is meant to provide a basic source of income in a very strong redistributive mood, emerging from the steep bend points of the formula relating pensions to average monthly earnings. Furthermore, a Supplemental Security Income (SSI, amounting in 2005 to 6948 dollars for a single person) is guaranteed to every citizen, and if Social security benefits do not reach this amount the difference is paid under SSI. Beyond this stage, further pension coverage is left to occupational or individual schemes, is more strongly correlated with earnings or contributions and does not explicitly aim at redistributive goals.

Do the European systems follow the same principles, irrespective of the different social models they represent? Adopting the simple dichotomy "bismarckian" versus "beveridgean" typologies allows one both to categorize the countries around the two elements of efficiency and redistribution and to make comparisons.

A basic, citizenship (or residence) related source of income for the elderly is present in all the seven countries of our sample. The amount of this support is of course variable from country to country, being broadly correlated with (but of course lower than) average income: a few years ago it ranged, for a single person, between 3621 euros in Spain and 10428 euros in the Netherlands (European Commission 2003, pp. 24-26). So far, there is no fundamental difference between the USA and Europe, nor within Europe.

In some countries, beyond these foundations, first pillar pensions follow a bismarckian scheme, since they aim at substituting during retirement, to a reasonable degree, the earnings levels enjoyed during the active life. This is true when benefits are linked to earnings (France, Germany and Spain), but also where (Italy and Sweden) NDC systems have been introduced: since the NDC system correlates benefits with contributions paid, and these are correlated with earnings, NDC is an indirect way of linking pensions to lifetime earnings ${ }^{20}$. In these countries, heavy state intervention takes place even without (or with little) redistribution. In other countries (the Netherlands and UK), the first pillar (a beveridgean one) does not try to mimic previous earnings, the link is weaker, and first pillar pensions are considerably lower than the earnings previously enjoyed.

\footnotetext{
${ }^{20}$ Of course, the higher the payroll tax rate (and consequently the replacement rate), the stronger is the link.
} 
In the former group of countries, public pensions are (or at least have been so far) deemed sufficient to afford a satisfactory income level during old-age, while in the latter the need of a second pillar has historically been felt more strongly.

b) The role of private pensions as a supplement to the public pension provision. There is therefore a clear negative correlation between the extension of the first and the second pillar. In table 2 (taking non availability as an indication of negligible importance), the countries ranking highest for first pillar replacement rates (Spain, Italy and France) do not show any role for the second; at the opposite end, in the Netherlands and the UK the second pillar replacement rates are stronger than those of the first; Sweden and Germany occupy an intermediate position ${ }^{21}$. Disney (2000, pp. 959-960) provides econometric evidence of this negative correlation ${ }^{22}$.

Moreover, since many of the recent reforms are negatively impacting (or will in the future) on the replacement rates offered by the first pillar, they have been accompanied by measures aiming at encouraging the growth of the second and third pillar (see sec. 5). Measures of this kind imply a long term process: a switch to more funding has a very small impact (or none at all) on the flow of pensions for many years, and in a period of transition the proportion of persons covered by a funded scheme may be much higher between workers than between pensioners. In terms of increased pension income, results will be felt only after decades. This is why forward looking data, such as the forecast of replacement rates and the percentage of covered workers, offer better information on future income flows than present ones. From these viewpoints, although the picture is not completely consistent ${ }^{23}$, Germany and Italy seem more promising than France and Spain.

c) Defined benefits vs. defined contributions. The move from defined benefits to defined contributions schemes, usually referred to when dealing with private funded schemes, is also taking place within public PAYG pillars. Some reforms of the latter tend to substitute the traditional earning based formulae, which correlates benefits to some average of the end-of-career (or of full life) wages, with a contributory formula, which implies both a stronger dependence of benefit on contributions and a closer proximity (when not a strict correspondence, as in the NDC system) of the internal rate of return to the equilibrium rate represented by the growth of the wage bill. Italy and Sweden have decided that future pension flows will be determined by contributions paid plus an implicit rate of return equal to the growth of the wage bill ${ }^{24}$. Of course, this rate is inherent in the very mechanism of PAYG, and any higher rate is not consistent in the long run with a balanced system and a constant payroll tax rate, but in the history of PAYG workers had been accustomed to higher pay-offs.

\footnotetext{
${ }^{21}$ The same ranking of the importance of the second pillar emerges from the contribution to pensioner's income as from table 3 .

22 The same point is also made by the European Commission (2003, pp. 78-80), Visco et al. (2005, pp. 5, 8 and 16) and Börsch-Supan (2004, pp. 8-13).

${ }^{23}$ While the Netherlands and the UK rank high under all these parameters, Germany shows an expected high coverage and a doubling of the replacement rate between 2003 and 2050, but a low assets/GDP ratio; Italy has a low coverage and a low assets/GDP ratio, but its replacement rate is expected (perhaps too bravely, as already mentioned) to rise from 0 to 20 per cent.

${ }^{24}$ So have done some new EU countries from Eastern Europe.
} 
In the private sector, the shift from defined benefits to defined contributions is well known ${ }^{25}$. Beyond the reasons connected with personnel management (see box 1 above), this shift is induced by the increasing, and in some instances destabilizing, cost of DB plans to employers. When the present value of future DB pensions is covered by the book reserve method, and a given class of assets is supposed to match it, the balance between the two items is a delicate one. The present value of future liabilities is not easy to assess, since it depends on the mobility of workers, the dynamics of their wages, and the chosen discount rate. The value of assets, in its turn, is subject to the vagaries of their prices: bull markets may induce firms to stop accumulating reserves (or even to reduce them), while bear markets may create huge unbalances ${ }^{26}$.

It is well known that many American and British firms have suffered heavily from the consequences of bear markets, and perhaps also from their short-sightedness, from their shrinking profits and from the lack of sufficiently stringent accounting rules $^{27}$. The increasing occurrence of these episodes cannot but be a further pressure away from defined benefits and towards defined contributions ${ }^{28}$.

d) Costs and Fees. Charges by pension funds may take different forms. Some are one-off, others are periodical, and may be fixed sums or percentages on contributions or on assets. Different types of fees may be translated, given some parameters (such as the length of the contribution period and the wage dynamics over such a period), in terms of a single measure. One of these measures is the reduction in yield, another is the "charge ratio", defined as one minus the final accumulation net of charges to the final accumulation without charges. All possible measures are somewhat correlated with each other, but they react differently to changes in parameters. For instance, the impact on the charge ratio of a given reduction in yield increases with the length of the accumulation period (for an analysis of different measures and of their reaction to changes in parameters, see Whitehouse 2000, sec. 2).

Looking at the reduction in yield (yearly charges expressed as a percentage of total assets), Mitchell (1998, p. 433) finds for the US a value of 0.23 per cent for single employer plans and 0.67 per cent for multiemployer plans ${ }^{29}$. For $401(\mathrm{k})$ plans, the figures are higher, ranging from 0.84 to 1.88 percentage points. Whitehouse (2000, pp. 34 and 37) indicates an order of magnitude of 0.75 per cent for large funds in Sweden and of 1.2-1.3 per cent in the UK (but the Turner Report, p. 8, reports only 0.3 per cent for employees of large firms). In Italy, the average figure is .45 per cent for occupational funds and 1.3 - 1.9 per cent for open funds (COVIP 2005, p. 93); a

\footnotetext{
${ }^{25}$ Buessing and Soto (2006) report data for U. S. bigger plans (100 or more participants, where DB has a higher probability of being adopted or maintained). Even within this set, between 1980 and 2003, DC has gradually overtaken DB in terms of participation rates, contributions paid, assets and benefits disbursed.

${ }^{26}$ For the dynamics of US pensions funds assets in the last decades, see Buessing and Soto (2006), p. 2 and Appendix Table E13.

27 These will change in the future, owing to the approval as of 2001 of the new International Accounting Standards, requiring an accounting method based on the notion, and an estimate, of the implicit pension debt.

28 A representative from Britain's National Association of Pension Funds, quoted by "The Economist" (January $28^{\text {th }} 2006$, p. 69), has gone as far as to forecast the disappearance of defined benefits from the private sector within five years.

${ }^{29}$ This difference may be due to the fact that "single-employer pension plan expenditures will tend to be underreported, inasmuch as the sponsoring companies absorb some portion of the plan's administrative costs" (Mitchell 1998, p. 432)
} 
different source (Fornero et al. 2004, p. 4) calculates, for open funds, a range of 1.07 1.46 per cent. The European Commission (2005, p. 24) concludes that in the member States "administrative costs generally range between $0.5 \%$ and $2.5 \%$ of assets per year; an average value of $1 \%$ per year appears to be most representative".

These averages appear to be acceptable, but their impact should not be understated. Over a 40 years contribution period (and with sensible values of the other parameters, such as a $4 \%$ gross real rate of return), a 1 per cent reduction in the yearly yield means a 20 per cent charge ratio: i. e. the final amount available for conversion into an annuity is 20 per cent less than it would be without costs.

Moreover, there is a relevant dispersion of charges around the average. Some, but not all, of the differences may be due to different services being offered to members. Economies of scale are obviously operating, but they apparently come to a halt at some level of assets (see World Bank 1994, p. 313; Whitehouse 2000, pp. 57-58). A strong impact on dispersion is due to the different nature of funds. Big occupational pension funds have no marketing costs, collect contributions directly from employers, enjoy economies of scale in record keeping, and, thanks to their bargaining power, obtain favourable conditions from asset managers and advisers. Smaller, "open" pension funds that address subscribers directly face a more difficult situation under all these viewpoints.

Some commentators argue that pension funds are very costly. Are there any policy options which could help reducing their charges? A number of interventions are possible. Some countries have mandated information and transparency procedures, as a first step not only for inducing informed choices, but also for fostering competition by facilitating comparisons between different funds. Several observers however think that the characteristics of pension funds hardly agree with the competitive market model, and that a sort of "consumer lethargy" is one of the reasons of the observed dispersion of charges (Diamond 1999b, pp. 19-20). Nevertheless, attempts may be made at reducing costs, for instance by collecting contributions through the same channel as social security. Some countries (such as Spain, Sweden, or the UK for the new "stakeholders" pensions) have set a ceiling on charges in terms of percentages on contributions or on the yearly balance of accounts ${ }^{30}$.

\section{The shift in the distribution of risk}

a) More risk unto the workers? In par. 3 it was claimed that a mixed system ensures a better allocation of risk with respect to a one-legged solution. The present general outlook, however, seem to reflect a riskier, not a safer, retirement provision: an apparent contradiction to the alleged superiority of the mixed system. But this superiority applies to a situation where the mix relates to two (or more) given schemes, while the recent trends imply not only a different blend of PAYG and funding, but also a dynamics of change within each of them. The diffusion of DC formulae within PAYG clearly implies an increase in the uncertainty surrounding the replacement rate at any

\footnotetext{
${ }^{30}$ Setting appropriate ceilings is of course a delicate task. Too low a level can drive funds into losses and therefore expel them from the market, or at least discourage them from improving the quality and range of services offered and from seeking professional advice on the choice of assets. Too high a level has no impact on reducing costs, and may even increase them by implicitly setting a standard of reference.
} 
given age of retirement ${ }^{31}$, and a lower degree of protection against a consumption shock as a retiree. The same transfer of risk applies to the scaling back from DB to DC occurring in occupational pension funds, by which financial risks are put onto the workers.

b) Rates of return. While offering some interesting prospects, the set of riskreturn combinations offered by a mixed portfolio cannot, so to speak, get rid of the constraints set by the component assets. In a balanced (currently and in perspective) PAYG scheme, the return on contributions, corresponding to the GDP growth rate, has relatively low volatility and, if the system is well designed, transparent and not too much fragmented, political risks are also kept at a low level, thus allowing for sensible anticipations of the prospective replacement rates. It is debatable whether the reform process has everywhere taken this path, but a good deal of progress is noticeable.

In the funded component, by contrast, the scaling back from DB to DC formulae brings in substantial risk. Siegel (1998, p. 32), for example, although emphasizing that over the 1802-1997 period the US stock market has offered an average yearly real rate of return of about 7 per cent, shows that five-year yearly averages oscillate between 26,7 and - 11 per cent; twenty-year averages range between 12,6 and 1 percent (see also Dimson et al. 2002, pp. 54-62). A worker unlucky enough to end his working career (and to convert his accumulated assets into an annuity) immediately after the -11 per cent five-year period or the -1 per cent twenty year period would find his yearly benefits much lower than expected. As has already been mentioned in sec. 3, some economists deem this risk to be unacceptable, and suggest some ways to share it. If this is not deemed possible, and if the risk aversion of the representative worker is assumed to be high, the weight of funding in the ideal mix ends up by being rather low.

c) Pension funds governance. Furthermore, the risk and return picture offered by market rates of return and their standard deviations is an incomplete one. Other risks cannot be compensated for by simple portfolio choices, and can only be neutralised through a wider diversification, involving the state, and by means of efficient and well regulated markets, again involving the state as regulator.

An important risk may be due to poor fund governance, inappropriate supervision or agency problems. The US have created the Pension Benefit Guarantee Corporation, a Federal agency against the insolvency of DB plans, that has been forced to intervene in a number of important cases, and has recently incurred in huge deficits. Similar problems have plagued the UK, where the Pensions Regulator, according to an Act passed in the year 2004, is charged to control and regulate pension funds and to monitor their risk profile; at the same time, a Pension Protection Fund has been created, with a task similar to the American PBGC. Regulatory issues, which should be directed at reducing some of the risks of private pensions, will be further examined in sec. 8 .

d) Participation risk. Left to their own choices, workers may tend to make little retirement savings, if at all. In this respect, the US experience is, again, illuminating. From the point of view of employees, it is important to stress that, in contrast to

\footnotetext{
${ }^{31}$ Italy provides a conspicuous example of this, since with the earning based formula the worker could safely count on a definite RR, such as 70-80 per cent of the average of the last 5 years of wages depending on the number of years of work (35-40 respectively). In the new NDC system, the contributory formula can only guarantee a rate of return equal to an average of GDP growth rates, and this does not easily translate into a promised replacement rate, which is perhaps the main reason why many Italian workers have not liked the 1995 pensions reform, which established this formula, irrespective of the political assurance that the reform aimed at a restored sustainability of the system.
} 
traditional DB plans, the voluntary nature of participation and contribution in $401(\mathrm{k})$ plans puts the responsibility of planning for retirement on individual workers. Calculations by Munnell and Sundén (2004, p. 56), based on the Survey of Consumer Finances, show that $25 \%$ of eligible workers do not participate in these plans, and the participation rate is positively and strongly correlated with income.

The low participation among low income workers raises concerns about the possibility that they can accumulate enough retirement wealth. One obvious reason why low earners do not participate in 401(k) plans is that they face liquidity constraint. But critics of the 401(k)'s institutional design argue that low participation is also due to other reasons, such as uninformed decisions: pension plans are not easy to understand, and individuals' reluctance may be enhanced by their overconfidence about their retirement wealth. There is important evidence that pension plans participation and contributions show a high level of inertia and procrastination. For example, 401(k) plans that provide automatic enrolment (the employee participates in the plan if he does not explicitly decide to opt out) have higher participation rates ${ }^{32}$.

A different but connected issue, for employees who have chosen to participate to a so-called member-directed pension plans, has to do with portfolio selection, which may be jeopardized by a low level of financial literacy (Lusardi and Mitchell, 2004) and possible inconsistencies in behaviour. A proper choice of default options may help to overcome, to some extent, these shortcomings.

e) Leakages. Furthermore, participation in a plan is not a sufficient condition for providing for old age. A source of concern is the possibility to access the fund before retirement, either by withdrawals or by borrowing from it (normally within limits set by law $)^{33}$. In addition, many $401(\mathrm{k})$ plans provide a lump sum distribution upon job termination. This decreases the accumulated capital at the time of retirement if the lump sum is not rolled over in an IRA or another $401(\mathrm{k})$ plan offered by the new employer ${ }^{34}$.

Of course, the extent to which the decision to withdraw, to borrow or not to roll over affects the future retirement wealth depends on what the worker decides to do with the cashed amount. If it is invested in forms other than a retirement account or used to reduce the outstanding level of liabilities, aside from differentials in the rate of return, the individual's net worth is not reduced ${ }^{35}$.

\footnotetext{
${ }^{32}$ Furthermore, participation is positively correlated with the presence of a matching contribution by the employer, while it is controversial, from both an empirical and theoretical perspective, whether it increases the employee's contribution rate.

33 This issue is controversial. Some argue that early withdrawals and borrowing add an element of liquidity to the plan, offering a buffer stock which a worker may rely on, and a source of financing for medical, educational or housing expenses. Munnell et al. (2002) find that the ability of borrowing from the plan increases, ceteris paribus, the participation and contribution rates.

${ }^{34}$ In order to stimulate people to roll over, a penalty on withdrawals before the age of 59 and a half that are not rolled over, and later a 20\% income tax, have been established. These normative actions appear to achieve their goal (Munnell and Sundén 2004, p. 133). Furthermore, it is worth noticing that there is a positive correlation between the level of the lump sum distribution and the likelihood to roll over. Studies in behavioural economics show that this could be due to a form of mental accounting that leads individuals to consider small amount as current income and not as assets.

${ }^{35}$ Munnell and Sundén (2004, p. 129) find that only a small share of loans is used to increase current consumption, while the majority used it either for consumer durables purchases or for housing, medical or educational expenses and investments.
} 
Many European countries (namely, those relying on voluntary participation) share the same problems as the US. As already mentioned, the recent reforms, while reducing the prospective replacement rates from the first pillar, have adopted measures aiming at strengthening the second one. By its nature, participation to the second pillar usually implies a greater degree of freedom and of individual decisions. So far, although the experience is as yet too short to elicit long term forecasts, the response seems to be significant only in Germany and is expected shortly to be so in Italy.

It follows that the greater degree of individual choices promoted by the introduction of private schemes, that in principle should allow a worker to maximize his utility, tailoring the plan's features on his particular preferences, could be dangerous in the presence of uninformed choices (Lusardi and Mitchell 2005). This is particularly true for low income workers that, as shown by the empirical evidence, are the ones that are more likely not to participate and to borrow from the account. The fact that participant choices show a high degree of inertia leaves space for the action of the policy maker in setting the default options in order to enhance private pension provision without decreasing the degree of individual choices.

f) Lump sums, annuities and longevity risk. Another concern often mentioned by critics of private DC plans is that "they fail to provide a formal mechanism by which individuals can insure against the risk of outliving their resources" (Brown and Warshawsky 2001, p. 1). In fact, DC plans may be so designed as to allow a choice between an annuity and a lump sum, or perhaps even termination in the form of a lump sum only.

In principle, even in the latter case employees may buy an annuity on the insurance market. This may however give rise to adverse selection, which in its turn generates a lower payout for the premium. In fact, in a DB plan that does not provide a lump sum option, covered workers cannot self select out of the annuity pool, while in a DC plan workers who think that they have lower mortality rates are more likely to join into the pool. Thus, the average life expectancy in the individual annuity market is higher than in a mandatory system, leading to a higher price of annuities. Furthermore, administrative costs are likely to be higher than in a group plan which benefits from economies of scale.

With the shift away from DB plans and the rising importance of DC plans, the rate of annuitization therefore tends to decline for future retirees, exposing them to a substantial longevity risk ${ }^{36}$. Being conscious of this danger, some EU countries have restricted the scope for lump-sum options (see European Commission 2005, p. 15).

Another weakness of annuities has to do with protection against inflation. In principle, nothing prevents insurance companies from offering annuities indexed to prices, either by taking the risk themselves or by investing their reserves in indexed assets (in which case, of course, the risk must be taken by someone else). A well functioning financial market should be able to develop such kind of debt; a firm should be inclined to issue it when its assets are implicitly linked to prices (or to some prices at least); so could the state, if not else because the yield from taxes is supposed to follow the price level (Mc Carthy and Mitchell, 2004). But the diffusion of indexed bonds and of indexed annuities is not generally developed; as long as this market (thanks to an

\footnotetext{
${ }^{36}$ Diamond (2004, pp. 5-7), after reviewing the reasons alleged to explain the limited use of annuities, concludes that "the major issue behind this pattern of insurance demand is the failure of many to understand the advantages of annuitization".
} 
evolution spurred by both demand and supply) does not expand, it is likely that DC pensions will offer an insufficient coverage against inflation ${ }^{37}$.

g) Income risks, insurance and redistribution. A further important feature differentiating DB from DC is the extent of (ex ante) redistribution. DB plans are not bound to follow actuarial rules, and may apply formulae which discriminate in favour of the poorest segments (this is of course particularly true for public, PAYG schemes: the American OASDI clearly favours low paid workers or short working lives), or of longer tenures, or of last period salaries. In principle, DC is prevented by financial and actuarial rules from implementing other than the "actuarial" kind of redistribution (i.e. the one which is implicit in different mortality patterns across socio economic groups).

An important caveat is that redistribution often implies a departure from efficiency; indeed, this is the price to be paid in order to reach a more equitable outcome. The point is: how high a price?

First, a degree of redistribution which softens too much the link between contributions paid and benefits received may reduce incentives and suggest free riding. If benefits affording an acceptable level of income are promised even after a limited contribution record (and in the limit irrespective of it), workers may be reluctant to join supplementary schemes and even tempted (if feasible) to underreport their true wages.

Second, attention must be paid to the fact that non-actuarial criteria which favour longer tenures or last period salaries do not necessarily mean helping the poorest segments; quite the opposite often happens. Benefits linked to last period salaries the more revalue past contributions, the longer and the steeper working careers have been, and favour workers with higher incomes. From the viewpoint of equity, this distortion has much to be regretted ${ }^{38}$.

When one of these two mechanisms is at work (or both are), a switch from DB to DC may be, from the point of view of both efficiency and social justice, not only acceptable but desirable. Yet, when DB rules pay proper attention to redistributing in the correct (progressive) direction, and to favouring poor (in terms of length and/or wages) lifetime histories or other needs (e.g. those of disabled workers, widows or young survivors), and when incentives are not (more than marginally) distorted, the shift from DB to DC implicitly means favouring a purely actuarial fairness, at the cost of a more equitable kind of redistribution. This loss of a welfare function is one of the objections raised by opponents to some of the reforms that took place in Europe and to the proposal of reforming the US Social Security by introducing personal accounts.

As a second approximation, it can be stressed that also DC schemes may include some redistributive element, e.g. financing through a public subsidy the accumulation of pension rights for periods of inactivity, such as maternity or childcare leave, unemployment, military service and the like (see European Commission 2005, p. 16). The device could also be implemented by matching the contributions made by poorer workers. Furthermore, a European directive (see box 2) provides that, after the year 2007 , there may be no differences between genders in the actuarial calculations, which favours women as enjoying a longer life expectancy. The difference between DB and

\footnotetext{
37 Also DB schemes do not always offer full coverage for inflation during retirement, but this is a technical detail which can be amended without any major change in the philosophy of the schemes.

${ }^{38}$ For instance, a lot of bad redistribution occurred in the pre-reform Italian system, which the 1992 and 1995 reforms set on a straighter path.
} 
DC, therefore, does not entirely correspond to accepting or refusing redistribution. As a matter of fact, however, DB is more easily associated with lack of actuarial equivalence between contributions and benefits and thus with possible forms of tilting, while the DC formula is more transparent and less prone to manipulation.

More generally, as emphasized by Diamond (2001, pp. 7-8), given that differently structured systems allocate differently the costs of shocks, it is the complete structure of the system that has to be taken into account. For example, when the system is mixed, lower incomes are covered mainly by PAYG, as the share of funding increases more than proportionally with income. Cuts in PAYG benefits thus fall disproportionately on low income people, while a bad realization of financial returns will hit primarily higher incomes people.

An appropriate allocation of risks can thus be obtained through risk sharing and pooling devices that go much further than just having a "partly funded-partly PAYG" scheme. It is a fundamental role of public policy to provide good rules and incentives for these devices to effectively work

\section{The role of regulation in the mitigation of risks}

After arguing that a mixed system is not, in itself, a sufficient condition to achieve a better return-risk combination when the whole risk structure is taken into consideration, we now turn to the features of the private component that are more likely to minimize its risks. Well functioning markets require significant government regulatory interventions. This is true in general, but particularly for private pensions, given that members and beneficiaries - i.e. the demand side of the market - are hardly in the position to compensate, for example through additional work, a bad outcome of their retirement savings. Rules are needed to protect participants from "excessive" financial risk; to encourage more activism on their part, possibly through greater financial education; to promote competition on the supply side; to enhance transparency in funds' governance and professional behaviour of the various entities involved.

International institutions such as the OECD have promoted guidelines, aimed at establishing good practices and at protecting members and beneficiaries (OECD 2002 and 2003). Investment regulation tends to move from quantitative restrictions towards process-based rules (such as the adoption of risk management models) and prudential criteria; in the case of DB pension plans, these guidelines are integrated with funding prescription; recommendations of asset management based on liabilities; adequate accounting valuation of the pension liability.

The guidelines laid out more specifically to protect members and participants refer to non-discriminatory access to pension plans and to ways to strengthen the adequacy of private schemes. The covered areas include: equal treatment, benefit accrual and vesting rights; pension portability; disclosure and availability of information.

At a more practical level, regulation and supervision of pension funds have been implemented by national states in a number of ways, such as "... mandating regular updates of longevity assumptions; providing incentives to pension fund plans sponsors to build reasonable and prudent funding buffers to withstand adverse shocks to assets and liabilities...; strengthening prudential elements of pension funds supervision, such as the use of sensitivity analysis and stress-testing; requiring legal separation of plans and plan sponsors..." (Visco et al. 2005, p. 6). 
Buffers above the full funding level - instead of contribution holidays - are often suggested against the risk of future under-funding (for DB pensions), an event which can be tolerated for short periods, provided that steps be taken in order to restore the full coverage of liabilities. Funds have often been encouraged to strengthen the correlation among maturities and the consistency of discount rates, i.e. to follow assets-andliabilities management rules. A frequent revision of mortality tables is also suggested in order to better adjust pension promises to the dynamics of life expectancy. Principles of asset composition are furthermore established, in some cases to the point of setting limits to the percentage of portfolio that may be invested in a given class (although incentives should be preferred to binding constraints, as an excess of regulation might hamper the attainment of the most appropriate risk-return combination). As a last resort, in a few cases, a government guarantee is accorded, although this is another debated subject, given the negative feedback on the incentive structure of both managers and participants ${ }^{39}$.

As far as the European Union is concerned, it must be recalled that, although pensions fall under the subsidiarity principle ${ }^{40}$, they are nevertheless so deeply connected with some of the policy goals dealt with in the Treaty, and particularly with the coordination of economic policies (art. 99) and with the sustainability of public finances, that a complete disregard of this subject would certainly be in contrast with the general spirit of the Treaty. After the June 2001 Gothenburg Council identified ageing population as a problem of paramount importance, a number of European Councils have given to the Social Protection Committee the mandate to study the long-term future of social protection, focusing in particular on the sustainability of pension schemes. The appropriate approach has been identified in the open method of coordination, which involves agreeing on broad common objectives, translating them into national policy strategies, working out "best strategies", and monitoring progress periodically ${ }^{41}$.

Member states have been asked to submit national strategy reports (the first was released in 2002 and the second in 2005) which are then merged in a joint report, assessing national strategies and identifying good practice. In one word, while restating the responsibility of each Member State for its own system, the institutions of the European Union have played an important role in monitoring national policies, suggesting common goals and favouring as much convergence as possible between the different systems.

As far as the second pillar is more directly concerned, the autonomy of the individual Member States in the domain of pension policy has not prevented the Council and the Commission from issuing a number of directives in some related topics which fall within their powers, notably the mobility of factors (work and capital). The most important ones are mentioned in box 3 .

\footnotetext{
${ }^{39}$ A broader analysis of different possible principles of regulation (prudent man, legislative intervention, information and accountability) and of their interactions is offered by Clark (2003).

40 "In accordance with the principle of subsidiarity, Member States should retain full responsibility for the organization of their pension systems as well as for the decision on the role of each of the three "pillars" of the retirement system...... In the context of the second pillar, they should also retain full responsibility for the role and functions of the various institutions providing occupational retirement benefits" (introductory remark no. 9 to Directive 2003/41 of the European Parliament and of the Council).

${ }^{41}$ The common objectives have been classified under three headings: adequacy (i. e. capacity to meet social objectives), financial sustainability and modernization (so as to better tackle mobility, flexibility and differential needs between genders).
} 


\section{Box 3. A focus on European directives}

Directive n. 49 of 1998 (a new draft on the same topic has been prepared in 2005 , and awaits the final approval) has to do with the portability of pension rights for workers moving from one member state to another. The aim is "to ensure that the rules governing the operation of [pension] schemes do not hamper the mobility of workers and reduce the opportunity for mobile workers to build up sufficient pension rights by the end of their careers, otherwise the flexibility and effectiveness of the labour markets would be reduced" (from the explanatory memorandum to the $2005 \mathrm{draft}$ ).

Directive n. 41 of 2003 is about "the activities and supervision of institutions for occupational retirement provisions". The focus of this directive is about prudential rules: member states are invited to insure that institutions for occupational retirement provisions are run by persons of good repute; that properly constituted rules are being implemented; that technical provisions are computed every year and certified by an actuary; that these provisions are covered by sufficient and appropriate assets; that members are sufficiently informed of the working of the pension scheme (investment policy, target level of retirement benefits, rules for the transfer of pension rights to another institution, and, on retirement, appropriate information on the benefits); that annual accounts and annual reports give a true and fair view of the institution's assets, liabilities and financial position. Member States shall ensure that the competent authorities have the power to ask information from the board of the institutions about all business matters (in particular about investment policy and actuarial valuations), to carry out on-site inspections and, in case of misbehaviour, to take any measures deemed necessary, including restrictions to the free disposal of the institution's assets or the transfer of powers to a special representative.

Directive n. 41 also looks to cross-border activities by stipulating that member states shall allow national institutions to appoint investment managers established in another member State and undertakings located within their territories to sponsor institutions for occupational retirement provisions located in other states, and vice-versa. Member states have been asked to comply with this directive before 23 September 2005.

Directive n. 113 of 2004 could also be mentioned, which deals with a broader theme (parity of treatment between men and women), and makes, within many others, the important point that, after the year 2007 , there may be no differences between genders as far as the actuarial calculations are concerned. A very important issue, which we do not tackle in this chapter.

An overall evaluation of these directives cannot but take into account the limits set by the Treaty to the interventions of the European Parliament and Council. The open method of coordination - while very useful in monitoring the situations of the single Member States, suggesting appropriate measures and favouring convergence - does not take the form of directives or other binding instruments. The directives applying to funded schemes do not interfere with the sovereign power of the individual member States to design their pension system, nor with the role they think it appropriate to entrust to each of the three pillars. The constitutional skeleton of pension system is left to the member States, and the European Union is concerned with favouring the free movement of workers and the free supply of financial services within the Union and the diffusion of proper instruments of prudential regulation. Whether this will be enough in 
the face of the important transfer of risk on the workers it is difficult to establish at this stage, but the feeling that the functioning of the European pension market can be strengthened and improved seems to indicate that a greater compliance with the guidelines set for by international institutions could be warranted.

\section{Conclusions}

A good pension system cannot be built in a vacuum: it implies some prerequisites. The most important one is an institutional and economic framework offering sufficient employment opportunities at acceptable levels of earnings ${ }^{42}$. Failing this condition, there is poverty everywhere in the economy, and no pensions alchemy can avoid poverty in old age. At the individual level, a working life as continuous as possible, at decent levels of earnings, is a necessary prerequisite for preparing - under any pillar - an acceptable income for pensioners. These problems can only be tackled by favouring appropriate institutions, widespread education, high activity rates and employment opportunities, technical progress and innovations, increases in the productivity of labour, and so on; in one word, this is not a task for pension policy but for a general growth policy.

When these preliminary conditions are satisfied, and the stage is set, a good pensions design is of paramount importance. But many problems are still ahead. First, even in high income countries, there may be pools of poverty. It may be debated, in view of the "free rider" risks involved, whether and how far a basic level of income should be guaranteed in old age to every citizen (or resident) irrespective of his contribution record. As it has been seen, all the countries considered in this paper have decided in the affirmative.

Over and above this first step, comes the choice of the other basic rules. In section 3 we showed our preference for a mixed system. But we have added many caveats: the introduction of funded pensions is no ready-made solution for the problems of an ageing society. Even in countries where this kind of pensions is an established and widespread tradition, and notwithstanding the basic support just mentioned, poverty among the elderly, particularly among elderly women, has not been eradicated. In the US, funded pension coverage reaches about fifty per cent of workers, but the average hides wide variations: participation rises sharply with earnings. This is another way of looking at the fact that, as has already been seen, one fifth of the over 65 get the whole of their income from Social Security. For the UK, the Turner report has emphasized that "the distribution of current pensioner income is highly unequal... also because of the wide dispersion of private pension provision" (p. 2), and that more than half the workers are not saving enough to reckon on a reasonable standard of living in their old age. The report therefore suggests more stringent participation rules (in the form of automatic enrolment, although subject to the right to opt out ${ }^{43}$ ) to pension funds.

In countries such as France and Spain, where the current coverage of funded pensions is rather low, the recent measures aimed at fostering it do not appear, so far, to have consistently reached their aim. In Italy, a years long debate on the diversion to pension funds of Trattamento di fine rapporto has ended up in a compromise, whereby

\footnotetext{
${ }^{42}$ We ask the reader to tolerate the terms "sufficient" and "acceptable", however vague they may appear.

${ }^{43}$ The rationale of this device is based on the assumption of a considerable degree of inertia in workers' behaviour.
} 
(after another two-years delay!) the diversion will take place for future yearly provisions (not for the stock accumulated so far), unless the worker does express a contrary opinion (which means that diversion will be the default option).

All these remarks lead to the important conclusion that an institutional setting providing for the existence, the regulation and possibly a favourable tax treatment of pension funds is a necessary, but not a sufficient, condition for filling any gap left by the public, PAYG component, nor for attaining a more balanced (whatever this word may mean) coexistence between the two pillars. Even when individual income levels would permit higher saving efforts for old age, workers do not always appear conscious of this need. One possible remedy is of course a greater informational and educational effort. Moreover, one should not forget that the very origins of social security are due to benevolent governments making it mandatory for workers to transfer part of their income from active life to old age. A higher level of compulsion, or at least of reliance on by default rules, might perhaps be suggested also for the second, funded pillar. Nor would this be seen as an unpleasant imposition, if it is true, as Boeri, Börsch-Supan and Tabellini (2001) have found, that most workers in France, Germany, Italy and Spain prefer a pension reform with mandatory savings over one with voluntary savings ${ }^{44}$.

The final conclusion cannot be but a reminder of the fundamentals of pensions policy. The formidable increase in life expectancy that has taken place for many decades, and will probably continue (although at an unknown rate) in the future, must be faced by the combination of an increase in the number of years worked and a further shift of purchasing power from the active to the inactive parts of human life. PAYG has proven to be a powerful method for effecting such a shift, but within limits. Countries that had not developed a significant funded pillar are now trying to do so. Those who had are reviewing the balance between the two pillars and the main features of each of them. Common problems do not necessarily lead to common solutions, but a convergent trend is slowly operating.

Old age benefits amount, in the countries we have considered, to between one tenth and one fifth of national incomes. When drawing the rules governing this huge flow of resources (between the young and the old age of an individual, or between the young and the old at a given time), political and social tensions must be faced and composed, and a carefully designed and long sighted strategy must be implemented. In the never ending effort to improve these rules, there are neither ready made formulae nor free meals.

\footnotetext{
${ }^{44}$ Mundell and Sundén (2004, p. 173) suggest the following principles: "all workers would be covered by a plan. Within each plan, participation and contributions would be automatic. Participants would not be able to cash benefits when they change jobs. The pattern of benefit accrual would not impede mobility or cause uneconomic incentives to retire early. Investment risk would be minimized, and benefits would be paid as an annuity and adjusted for inflation after retirement".
} 


\section{References}

Board of Trustees of the Federal OASI and DI Trust Funds (2005), The 2005 Annual Report, Washington, US Government Printing Office, www.socialsecurity.gov/OACT/pubs.htlm/TR

Bodie, Z., A. Marcus and R. Merton (1988), Defined Benefit versus Defined Contribution Pension Plans: What are the Real Trade-offs? in Bodie, Z., J. Shoven and D. Wise. (eds.), Pensions in the US Economy, Chicago, University of Chicago Press.

Boeri, T., A. Börsch-Supan and G. Tabellini (2001), Would you Like to Shrink the Welfare State? A Survey of European Citizens, "Economic Policy", no. 32, April.

Börsch-Supan, A. (2004), Mind the Gap: The Effectiveness of Incentives to Boost Retirement Saving in Europe, mimeo.

Börsch-Supan, A. et al. (2005), Health, Ageing and Retirement in Europe, Mannheim Research Institute for the Economics of Ageing.

Brown, J. R. and M. J. Warshawsky (2001), Longevity-insured retirement distributions from pension plans: market and regulatory issues, NBER Working Paper n. 8064

Buessing, M. and M. Soto (2006), The State of Private Pensions: Current 5500 Data, Center for Retirement Research at Boston College Issue in Brief, no. 42, February.

Castellino, O. and E. Fornero (2003), Pension Policy in an Integrating Europe, Cheltenham, Edward Elgar.

Clark, G. (2003), Pension Fund Governance: Moral Imperatives, State Regulation, and the Market, mimeo.

Clark, R. and S. Schieber (2004), The Transition to Hybrid Pension Plans in the United States: An Empirical Analysis, in Gale, W. G., J. B. Shoven and M. J. Warshawsky (eds.), Private Pensions and Public Policies, Washington, Brookings Institution.

COVIP (Commissione di Vigilanza sui Fondi pensione) (2005), Relazione per l'anno 2004, Rome.

Diamond, P. (1999a), What Stock Market Returns to Expect for the Future?, "Issues in Brief", n. 2, Centre for Retirement Research, Boston College.

Diamond, P. (1999b), Administrative Costs and Equilibrium Charges with Individual Accounts, NBER Working Paper no. 7050, March.

Diamond, P. (2001), Towards an Optimal Social Security Design, CeRP Working Paper no. $4 / 01$.

Diamond, P. (2004), Social Security, “American Economic Review”, vol. 94, no. 1, March, pp. 1-24.

Diamond, P. and P. Orszag (2004), Saving Social Security - A Balanced Approach, Washington, Brookings Institution.

Dimson, E., P. Marsh and M. Staunton (2002), The Triumph of the Optimists, Princeton, Princeton University Press. 
Disney, R. (2000), Declining Public Pensions in an Era of demographic Ageing: Will Private Provision fill the Gap?, "European Economic Review", 44, pp. 957-973.

Esping Andersen, G. (1990), The Three Worlds of Welfare Capitalism, Policy Press, London.

European Commission (2003), Adequate and Sustainable Pensions - Joint Report by the Commission and the Council, Bruxelles, September.

European Commission, The Social Protection Committee (2004), Current and Prospective Pension Replacement Rates - Report on Work in Progress, Bruxelles, February.

European Commission, The Social Protection Committee (2005), Privately Managed Pension Provision, Bruxelles, February.

Eurostat (2004), Classification of Funded Pension Schemes and Impact on Government Finance, Methods and Nomenclatures, theme 2, 2004.

Federal Interagency Forum on Aging-Related Statistics (2000), Older Americans 2000: Key Indicators of Well-being, Washington, DC, US Government Printing Office.

Feldstein, M. (1996), The Missing Piece in Policy Analysis : Social Security Reform, "American Economic Review - Papers and Proceedings", vol. 86, no. 2, May.

Fornero, E., C. Fugazza and G. Ponzetto (2004), A Comparative Analysis of the Costs of Italian Individual Pension Plans, CeRP Working Paper no. 33/04.

Holzmann, R. and R. Hinz (2005), Old-Age Income Support in the Twenty-first Century: An International Perspective on Pensions Systems and Reform, Washington, The World Bank.

Lindbeck, A. and M. Persson (2003), The Gains from Pension Reform, "Journal of Economic Literature", vol. XVI, no. 1, March.

Lusardi, A., and O. Mitchell (2005), Financial Literacy and Planning: Implications for Retirement Wellbeing, CeRP WP no. 46.

McCarthy, D. and O. Mitchell (2004), “Annuities for an Ageing World” in Fornero E. and E. Luciano (eds), Developing an Annuity Market in Europe, Cheltenham, Edward Elgar.

Mitchell, O. (1998), Administrative Costs in Public and Private Retirement Systems, in M. Feldstein (ed.), Privatizing Social Security, Chicago, University of Chicago Press.

Modigliani, F., M. L. Ceprini and A. Muralidhar (2001), A Better Solution to the Social Security Problem: Funding with a Common Portfolio, MIT Sloan Working Paper.

Modigliani, F., and A. Muralidhar (2004), Rethinking Pension Reform, Cambridge, Cambridge University Press.

Munnell, A. H. and A. Sundén (2001), Private pensions: coverage and benefits trends, paper prepared for "Conversation on Coverage", Washington.

Munnell, A. H. and A. Sundén (2004), Coming Up Short - the Challenge of 401( $\mathrm{k}$ ) Plans, Washington, Brookings Institution Press.

Munnell, A. H., A. Sundén and C. Taylor (2002), What determines 401(k) participation and contributions?, "Social Security Bulletin", 64, 3, 64-75. 
National Strategy Reports, http://europa.eu.int/comm/employment_social/social_protection/ pensions en.htm

OECD (2002), Guidelines for Pension Fund Governance, Paris; http://www.oecd.org/dataoecd/22/2/2767694.pdf.

OECD (2003) Guidelines for the Protection of Rights of Members and Beneficiaries in Occupational Pension Plans, Paris; http://www.oecd.org/dataoecd/16/33/34018295.pdf

OECD (2005a), Private Pensions - OECD Classification and Glossary, Paris.

OECD (2005b), Pension Markets in Focus, Issue 2, December.

Pensions Commission appointed by the UK Secretary of State for Work and Pensions (2005), Second Report: A New Pensions Settlement for the $21^{\text {st }}$ Century ("Turner Report”), http://www.pensionscommission.org.uk

President's Commission to Strengthen Social Security (2001), Report, www.csss.gov/reports/Final_report.pdf

Siegel, J. (1998), Stocks for the Long-Run: the Definitive Guide to Financial Market Returns and Long-Term Investment Strategies, $2^{\text {nd }}$ edition, New York, McGrawHill.

Tobin, J. (1965), The Theory of Portfolio Seection, in Hahn, F. and F. Bechling (eds.), The Theory of Interest Rates, London, Macmillan.

US Department of Labor (2005), Private Pension Plan Bulletin (Preliminary), www.dol.gov/ebsa/publications/main.htlm

US Social Security Administration (2005), The Future of Social Security, www.socialsecurity.gov/pubs/10055.htlm

Visco, I. et al. (2005), A Report prepared at the Request of the Deputies of the Group of Ten by an experts group chaired by Ignazio Visco, September.

Whitehouse, E. (2000), Administrative Charges for Funded Pensions: An International Comparison and Assessment, World Bank Social Protection Discussion Paper no. 0016, June.

World Bank (1994), Averting the Old Age Crisis, Oxford University Press for the World Bank. 
Our papers can be downloaded at:

$\underline{\text { http://cerp.unito.it }}$

\section{CeRP Working Paper Series}

\begin{tabular}{|c|c|c|}
\hline $\mathrm{N}^{\circ} 1 / 00$ & Guido Menzio & Opting Out of Social Security over the Life Cycle \\
\hline $\mathrm{N}^{\circ} 2 / 00$ & $\begin{array}{l}\text { Pier Marco Ferraresi } \\
\text { Elsa Fornero }\end{array}$ & $\begin{array}{l}\text { Social Security Transition in Italy: Costs, Distorsions and (some) } \\
\text { Possible Correction }\end{array}$ \\
\hline $\mathrm{N}^{\circ} 3 / 00$ & $\begin{array}{l}\text { Emanuele Baldacci } \\
\text { Luca Inglese }\end{array}$ & $\begin{array}{l}\text { Le caratteristiche socio economiche dei pensionati in Italia. } \\
\text { Analisi della distribuzione dei redditi da pensione (only available } \\
\text { in the Italian version) }\end{array}$ \\
\hline $\mathrm{N}^{\circ} 4 / 01$ & Peter Diamond & Towards an Optimal Social Security Design \\
\hline $\mathrm{N}^{\circ} 5 / 01$ & Vincenzo Andrietti & $\begin{array}{l}\text { Occupational Pensions and Interfirm Job Mobility in the } \\
\text { European Union. Evidence from the ECHP Survey }\end{array}$ \\
\hline$N^{\circ} 6 / 01$ & Flavia Coda Moscarola & $\begin{array}{l}\text { The Effects of Immigration Inflows on the Sustainability of the } \\
\text { Italian Welfare State }\end{array}$ \\
\hline $\mathrm{N}^{\circ} 7 / 01$ & Margherita Borella & $\begin{array}{l}\text { The Error Structure of Earnings: an Analysis on Italian } \\
\text { Longitudinal Data }\end{array}$ \\
\hline $\mathrm{N}^{\circ} 8 / 01$ & Margherita Borella & $\begin{array}{l}\text { Social Security Systems and the Distribution of Income: an } \\
\text { Application to the Italian Case }\end{array}$ \\
\hline $\mathrm{N}^{\circ} 9 / 01$ & Hans Blommestein & $\begin{array}{l}\text { Ageing, Pension Reform, and Financial Market Implications in } \\
\text { the OECD Area }\end{array}$ \\
\hline $\mathrm{N}^{\circ} 10 / 01$ & $\begin{array}{l}\text { Vincenzo Andrietti and Vincent } \\
\text { Hildebrand }\end{array}$ & $\begin{array}{l}\text { Pension Portability and Labour Mobility in the United States. } \\
\text { New Evidence from the SIPP Data }\end{array}$ \\
\hline $\mathrm{N}^{\circ} 11 / 01$ & $\begin{array}{l}\text { Mara Faccio and Ameziane } \\
\text { Lasfer }\end{array}$ & $\begin{array}{l}\text { Institutional Shareholders and Corporate Governance: The Case } \\
\text { of UK Pension Funds }\end{array}$ \\
\hline $\mathrm{N}^{\circ} 12 / 01$ & Roberta Romano & $\begin{array}{l}\text { Less is More: Making Shareholder Activism a Valuable } \\
\text { Mechanism of Corporate Governance }\end{array}$ \\
\hline $\mathrm{N}^{\circ} 13 / 01$ & Michela Scatigna & Institutional Investors, Corporate Governance and Pension Funds \\
\hline$N^{\circ} 14 / 01$ & Thomas H. Noe & Investor Activism and Financial Market Structure \\
\hline$N^{\circ} 15 / 01$ & Estelle James & $\begin{array}{l}\text { How Can China Solve ist Old Age Security Problem? The } \\
\text { Interaction Between Pension, SOE and Financial Market Reform }\end{array}$ \\
\hline $\mathrm{N}^{\circ} 16 / 01$ & $\begin{array}{l}\text { Estelle James and } \\
\text { Xue Song }\end{array}$ & $\begin{array}{l}\text { Annuities Markets Around the World: Money's Worth and Risk } \\
\text { Intermediation }\end{array}$ \\
\hline $\mathrm{N}^{\circ} 17 / 02$ & $\begin{array}{l}\text { Richard Disney and } \\
\text { Sarah Smith }\end{array}$ & $\begin{array}{l}\text { The Labour Supply Effect of the Abolition of the Earnings Rule } \\
\text { for Older Workers in the United Kingdom }\end{array}$ \\
\hline $\mathrm{N}^{\circ} 18 / 02$ & Francesco Daveri & $\begin{array}{l}\text { Labor Taxes and Unemployment: a Survey of the Aggregate } \\
\text { Evidence }\end{array}$ \\
\hline $\mathrm{N}^{\circ} 19 / 02$ & $\begin{array}{l}\text { Paolo Battocchio } \\
\text { Francesco Menoncin }\end{array}$ & $\begin{array}{l}\text { Optimal Portfolio Strategies with Stochastic Wage Income and } \\
\text { Inflation: The Case of a Defined Contribution Pension Plan }\end{array}$ \\
\hline$N^{\circ} 20 / 02$ & Mauro Mastrogiacomo & Dual Retirement in Italy and Expectations \\
\hline$N^{\circ} 21 / 02$ & $\begin{array}{l}\text { Olivia S. Mitchell } \\
\text { David McCarthy }\end{array}$ & Annuities for an Ageing World \\
\hline
\end{tabular}


Chris Soares Mark Warshawsky

$\mathrm{N}^{\circ} 23 / 02 \quad$ Ermanno Pitacco

$\mathrm{N}^{\circ}$ 24/02 Laura Ballotta Steven Haberman

$\mathrm{N}^{\circ} 25 / 02$ Edmund Cannon Ian Tonks

$N^{\circ} 26 / 02 \quad$ E. Philip Davis

$N^{\circ}$ 27/02 Reinhold Schnabel

N ${ }^{\circ} 28 / 02 \quad$ Luca Spataro

N ${ }^{\circ} 29 / 02 \quad$ Marco Taboga

$\mathrm{N}^{\circ} 30 / 03 \quad$ Bas Arts

Elena Vigna

№ 31/03 Giacomo Ponzetto

N ${ }^{\circ} 32 / 04 \quad$ Angelo Marano

Paolo Sestito

$\mathrm{N}^{\circ} 33 / 04 \quad$ Elsa Fornero

Carolina Fugazza

Giacomo Ponzetto

N 34/04 Chourouk Houssi

$\mathrm{N}^{\circ}$ 35/04 Monika Bütler

Olivia Huguenin

Federica Teppa

$N^{\circ} 36 / 04 \quad$ Laurence J. Kotlikoff

$N^{\circ} 37 / 04 \quad$ Jay Ginn

№ 38/05 Carolina Fugazza

Federica Teppa

N ${ }^{\circ} 39 / 05 \quad$ Anna Rita Bacinello

$N^{\circ} 40 / 05 \quad$ Carolina Fugazza

Massimo Guidolin

Giovanna Nicodano

$\mathrm{N}^{\circ}$ 41/05 Massimo Guidolin

Giovanna Nicodano

$\mathrm{N}^{\circ} 42 / 05 \quad$ Margherita Borella

Flavia Coda Moscarola

$\mathrm{N}^{\circ} 43 / 05 \quad$ John Beshears

James J. Choi

David Laibson

Brigitte C. Madrian
Annuity Risk: Volatility and Inflation Exposure in Payments from Immediate Life Annuities

Longevity Risk in Living Benefits

Valuation of Guaranteed Annuity Conversion Options

The Behaviour of UK Annuity Prices from 1972 to the Present

Issues in the Regulation of Annuities Markets

Annuities in Germany before and after the Pension Reform of 2001

New Tools in Micromodeling Retirement Decisions: Overview and Applications to the Italian Case

The Realized Equity Premium has been Higher than Expected: Further Evidence

A Switch Criterion for Defined Contribution Pension Schemes

Risk Aversion and the Utility of Annuities

Older Workers and Pensioners: the Challenge of Ageing on the Italian Public Pension System and Labour Market

A Comparative Analysis of the Costs of Italian Individual Pension Plans

Le Vieillissement Démographique :

Problématique des Régimes de Pension en Tunisie

What Triggers Early Retirement. Results from Swiss Pension Funds

Pensions Systems and the Intergenerational Distribution of Resources

Actuarial Fairness or Social Justice?

A Gender Perspective on Redistribution in Pension Systems

An Empirical Assessment of the Italian Severance Payment (TFR)

Modelling the Surrender Conditions in Equity-Linked Life Insurance

Investing for the Long-Run in European Real Estate. Does Predictability Matter?

Small Caps in International Equity Portfolios: The Effects of Variance Risk.

Distributive Properties of Pensions Systems: a Simulation of the Italian Transition from Defined Benefit to Defined Contribution The Importance of Default Options for Retirement Saving Outcomes: Evidence from the United States 
$\mathrm{N}^{\circ} 45 / 05$

Claudio Campanale

$\mathrm{N}^{\circ} 46 / 05$

Annamaria Lusardi Olivia S. Mitchell

$N^{\circ} 47 / 06 \quad$ Michele Belloni Carlo Maccheroni

$\mathrm{N}^{\circ} 48 / 06 \quad$ Onorato Castellino Elsa Fornero
Advertising and Portfolio Choice

Increasing Returns to Savings and Wealth Inequality

Financial Literacy and Planning: Implications for Retirement Wellbeing

Actuarial Neutrality when Longevity Increases: An Application to the Italian Pension System

Public Policy and the Transition to Private Pension Provision in the United States and Europe 